ろが多い。

（昭和 37 年 10 月 1 日受理）

文献

1) 北原, 本誌 9, 169 (1960)

2) N.L. Jarvis, W.A. Zisman, J. Phys. Chem., 64, 150 (1960)

3) S. Ross, J.P. Olivier, ibid., 63, 1671 (1959)

4) P. Becher, ibid., 64, 1221 (1960)

5) M. Davies, G. Williams, Trans. Faraday Soc., 56, 1619 (1960)

6) N. Robinson, J. Phar. Pharmacol., 12, 685 (1960)

7) N. Pilpel, Trans. Faraday Soc., 57, 1426 (1961)

8) P. Debye, W. Prins, J. Colloid Sci., 13, 86 (1958)

9) P. Debye, H. Coll, ibid., 17, 220 (1962)

10) A. Kitahara, T. Kobayashi, T. Tachibana, J.Phys. Chem:, 66, 363 (1962)

11) F.M. Fowkes, M.J. Schick, A. Bondi, J. Colloid Sci., 15, 531 (1960)

12) E. Hutchinson (北原訳), 化学と工業, 13，654 (昭 35)

13) H. Reerink, "Proc. 3rd. Int. Conference of Surface Activity", Vol II, p. 255 (1960)

14) W.J. Archibald, J. Phys. Colloid Chem., 51, 1204 (1947)

15) F.M. Fowkes, Lecture on 36th National Colloid Symposium of U.S. at Stanford University (June, 1962)

16) S. Kaufman, C.R. Singleterry, J. Colloid Sci., 10, 139 (1955); 12, 465 (1957)

17) A. Kitahara, Bull. Chem. Soc. Japan, 28,234(1955);
29, 15 (1956); J. Colloid Sci., 12, 342 (1957)

18) S. Kaufman, C.R. Singleterry, J. Phys. Chem., 62, 1257 (1958)

19) P.M. Elworthy, J. Chem. Soc., 1959, 813

20) P.M. Elworthy, ibid., 1959, 1951

21) M. Shirai, Sci. Papers College of Gen. Edu., Univ. of Tokyo, 6, 147 (1956)

22) W.D. Bascom, C.R. Singleterry, J. Colloid Sci., 13, 569 (1958)

23) S. Kaufman, ibid., 17, 231 (1962)

24) P.A. Demchenko, Kolloid Zhur., 22, 297 (1960)

25) C.M. Aebi, J.R. Wiebush, .J. Colloid Sci., 14, 161 (1959)

26) S.R.Palit, V.A. Maghe, B. Biwas, Trans. Faraday Soc., 55, 463 (1959)

27) S.R. Palit, V. Venkateswarlu, J. Chem. Soc., 1954, 2129

28）石渡，コロイドと界面活性剤，2,557，634 (1961)

29) V.R. Damerell, A. Urbanic, J. Phys. Chem., 48, 125 (1944)

30) V.R. Damerell, K. Gayer, H. Laudenslayer, ibid., 46, 436 (1945)

31) M. van der Waarden, J. Colloid Sci., 5, 317 (1950); 6, 443 (1951)

32) M. Hayek, J: Phys. Colloid Chem., 55, 1527 (1951)

33) J.L. van der Minne, P.H.J. Hermanie, J. Colloid Sci., 8, 38 (1953)

34) J. Briant, B. Bernelin, Rev. Inst. France Pétrole, 16, 1767 (1961)

\title{
界面活性剤の吸着とらポテンシャル
}

須 沢 利 郎*

\author{
Absorption and $\zeta$ Potential of Surface Active Agents
}

Toshirō Suzawa

界面活性剤分子は親水基と疎水基を有し，乙の両者が 吸着に関与するのであるが，その配向の状態によって極 性吸着あるいは非極性吸着をする。

らポテンシャルの研究も当然界面活性剤のてのような 吸着性との関連において行なわれている。また対象とな る界面はそのほとんぞが固-液界面，特に界面活性剂水 溶液中における繊維物質あるいは粉体の場合が多い。

界面活性剤は之セル 形成臨界濃度 (CMC) を有する が，CMC 以下の濃度においては，界面活性剤は単一イ オンまたは単一分子として在存する叻，界面活性㓮の 吸着性は $\mathrm{CMC}$ 以上の濃度のときよりもより 単純であ り,したがって測定されたらポテンシャルの解釈も容易 であろう。

したがって本稿では界面活性剤水溶液中における繊維 物質あるいは粉体のらポテンシャルを，てれらの固体面 における界面活性剤の吸着性との 関連において 取り上 げ,はじめに CMC 以下の濃度範囲,つぎに CMC 付近

\footnotetext{
* 大阪市立工業研究所 (大阪市北区北扇町)
}

Osaka Municipal Technical Research Institute
の濃度範畘について述べる。またらポテンシャルは固一 液界面のみ限っても, その工業の実際との関連は深く 染色, 洗浄, 浮遊選鉱あるいは製紙（サイジング工程） なぞ，界面活性剂の関与する分野も相当広いが，本稿で は，洗浄および浮遊選鉱についておもに述べ，染色その 他については簡単にふれるにとどめる。

なおらポテンシャルの原理的な面については, 種々の 成書もあり,紙数の関係もあるので省略させていただく。

\section{CMC 以下の界面活性剂濃度の場合}

$\mathrm{CMC}$ 以下の低濃度の界面活性剂水溶液中における繊 維物質のらポテンシャルの測定例としては，モメン，絹 および羊毛などの天然瀻維 ${ }^{1), 21}$, ビスコース人絹, アセ テートなどの再生あるいは半合成繊維 ${ }^{2)}$, さらにナイロ

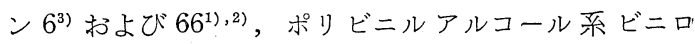
ン)，ポり塩化ビニル系テビロン ${ }^{5)}$ ，ポアクリロニトリ

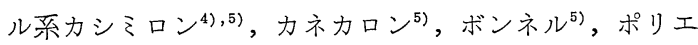
ステル系テトロン4)，およびポリエチレン系八イゼック $ス^{6)}$ などの合成繊維がある。粉体の例としては, 浮遊選 
鉱との関係で石英がよく研究されている 洗浄におけるよでれのモデル物質として，カーボン，酸 化鉄およびパラフィン油滴などが研究されているが，て れらについては洗浄作用の項で述べることにする。以下 種々の条件による変化と界面活性剤の吸着性について述 べる。

なお拡散電気二重層におけるイオンのボルツマン分布 を仮定するととによって，らポテンシャルより，固体表 面の電荷密度 $\sigma$ を求め, 界面活性剂分存在する系々存在 しない系につ认ての電荷密度の差 $\Delta \sigma$ を求め, $\Delta \sigma$ あるい は・ $\Delta \sigma$ より算出できる固体の表面吸着量と種々の条件と の関係を調べた例もある ${ }^{1), 3) 。 ~}$

\section{1 界面活性剂濃度}

陰イオン界面活性剂ドデシル硫酸ナトリウムSDS 水 溶液中のモメンと羊毛の $\zeta$ ポテンシャルおよび $\Delta \sigma$ の界 面活性剤濃度による変化を示したのが図-1である。

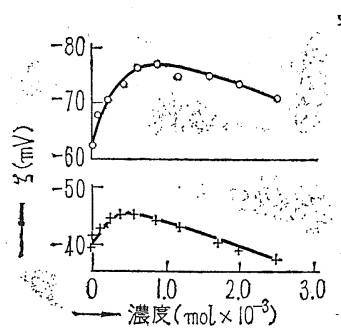

(a)

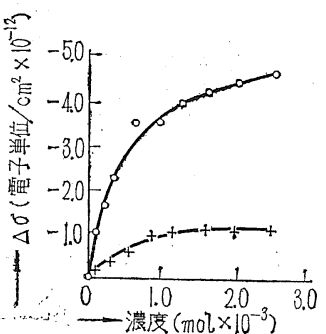

(b)
$\mathrm{pH} 11,25^{\circ} \mathrm{C}$, 一-0- 羊毛

图-1

界面活性剂 $\left(\mathrm{CMC} 5.8 \times 10^{-3} \mathrm{~mol}\right)$ 濃度の増加ととも に, 一ちは増加し, ある濃度で極大を示し, 以後減少す る。この際の極大を示す濃度は,繊維によって異なり,モ メンでは羊毛よりも低濃度で現われる。ほがも同様の ととが認められており ${ }^{2)}$ ，テトラデシル硫酸ナトリウム STS でも起てる。乙の原因として, 繊維による表面構 造の相違々電気二重層の厚さの圧縮の差違が考えられ る。また繊維表面の吸着量に相応する $\Delta \sigma$ は，モメンの場 合 $0.001 \mathrm{~mol}$ で飽和吸着をしているととを示すが, 羊毛 では $0.0025 \mathrm{~mol}$ でもなお飽和せず，羊毛の方がドデシ ル硫酸陰イオンをより多く吸着するととを示す。また羊 毛の等電点はこの際用いられたものについては $\mathrm{pH} 3.4$ であるので, $\mathrm{pH} 11$ では羊毛は負電荷を有すると考学ら れ，モメンについても同様であるので，てれらの結合は ファンデルワールスカなどによるものと思われる。

また図-2に示したように，ナイロンで繊維と界面 活性剤が逆符号の電荷を有するときは, 界面活性剤濃度 の増加とともに 剤 SDS ではそのーてを増し, 陽イオン界面活性剤ドデ シルピリジニウムブロミド DPB ( $\mathrm{pH} 6$ で $\mathrm{CMC} 9.3 \times$ $\left.10^{-3} \mathrm{~mol}\right)$ ではその+らを増して, 静電結合が支配的で あるととを示す ${ }^{11}$ 。
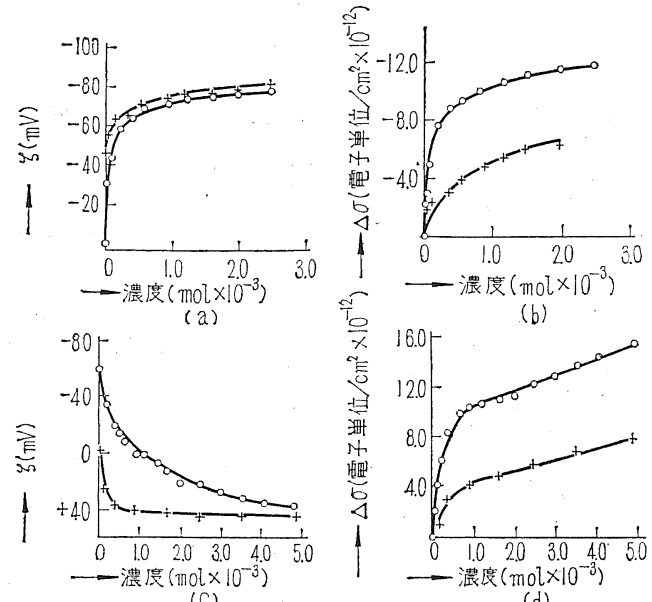

(d)

(b),(b); SDS, pH $11-+-+, \mathrm{pH} 3 \longrightarrow 0-0-0-$

(c),(d); DPB, pH $11-0-0-, \mathrm{pH} 3-+-+-$

図-2

得られた $\Delta \sigma$ より, 界面活性剂の CMC 以下の濃度で は飽和吸着にならないととがわかる。

ポリエチレン系八イゼックス瀻維では, 図-3および 表-1のように，陽イオン界面活性剤 DPBでは+らを 增すが，陰イオン界面活性剤 SDS では，瀻維自身かな り負のらポテンシャルを有するにもかかわらず, 界面活 性剤濃度の増加とともに一らか急激に増加し, また表面 吸着量も増加している。

てのととは静電的な反發力が作用するにもかかわら ず，ファンデルワールスカなどの関与があるととを示

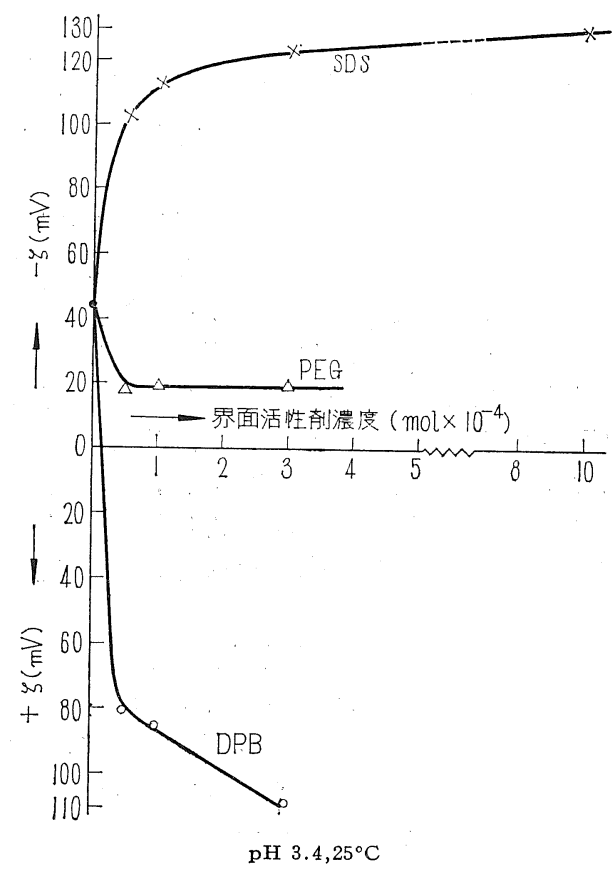

図-3 
表-1ポリエチレン系ハイゼックス繊維, $\mathrm{pH} 3.4$, $25^{\circ} \mathrm{C}$ 界面活性荗濃度一 $\zeta$ ポテンシャルー表面 電荷密度-表面吸着量の関係

1) $\mathrm{SDS}$

\begin{tabular}{|c|c|c|c|c|}
\hline $\begin{array}{l}\mathrm{SDS} \text { 濃度 } \\
\mathrm{mol} \times 10^{-4}\end{array}$ & $\begin{array}{c}-\zeta \\
(\mathrm{mV})\end{array}$ & $\begin{array}{c}-\sigma \\
\left.\text { (e.s.u. } / \mathrm{cm}^{2}\right)\end{array}$ & $\begin{array}{c}-\Delta \sigma \\
\left(\text { 電子単位/ } / \mathrm{cm}^{2} \text { ) }\right. \\
\times 10^{-12}\end{array}$ & $\begin{array}{l}\text { 表面吸着量 } \\
\left(\mathrm{g} / \mathrm{cm}^{2}\right)^{10} \\
\times 10^{10}\end{array}$ \\
\hline 0.0 & 43.6 & 669.4 & 0.0 & 0.0 \\
\hline 0.5 & 101.9 & $2,628.6$ & 4.1 & 19.5 \\
\hline 1.0 & 112.5 & $3,492.5$ & 5.9 & 28.1 \\
\hline 3.0 & 121.9 & $4,819.1$ & 8.6 & 41.3 \\
\hline 10.0 & 128.1 & $7,955.9$ & 15.2 & 72.6 \\
\hline
\end{tabular}

\begin{tabular}{|c|c|c|c|c|}
\hline \multicolumn{5}{|l|}{ 2) $\mathrm{DPB}$} \\
\hline $\begin{array}{l}\mathrm{DPB} \text { 濃度 } \\
\mathrm{mol} \times 10^{-4}\end{array}$ & $\begin{array}{c}+\zeta \\
(\mathrm{mV})\end{array}$ & $\begin{array}{c}+\sigma \\
\left(\text { e.s.u. } / \mathrm{cm}^{2}\right)\end{array}$ & $\left\{\begin{array}{c}+\Delta \sigma \\
\left(\text { 電子単位 } / \mathrm{cm}^{2}\right) \\
\times 10^{-12}\end{array}\right.$ & $\begin{array}{c}\text { 表面吸着量 } \\
\left(\mathrm{g} / \mathrm{cm}^{2}\right) \\
\times 10^{10}\end{array}$ \\
\hline 0.0 & -43.6 & -669.4 & 0.0 & 0.0 \\
\hline 0.5 & 80.9 & $1,717.4$ & 5.0 & 27.1 \\
\hline 1.0 & 85.2 & $1,967.9$ & 5.5 & 29.9 \\
\hline 3.0 & 109.0 & $3,741.4$ & 9.2 & 50.0 \\
\hline
\end{tabular}

す。同様のととは程度の差はあるが，ビニロン，カシミ ロンなどについても認められている4゙,5)。

つぎに非イオン界面活性剤の場合であるが，図-3 示したように, ポリエチレン系ハイゼックス繊維のらポ テンシャルは, ポリオキシェチレンノニルフェニルエー テル $(n=15)$ PEG の水溶液中では, 界面活性剤濃度の 増加とともに一らが減少し，ある濃度より一定の值を示 す。同様のことはドデシルアルコールエチレンオキシド 付加物 $(n=10)$ その他において, 各種の繊維について認 められており 2),4)，それはこれらのエチレンオキシド付 加物が $\mathrm{H}^{+}$などによってオキソニウム化合物になる ${ }^{11)}$ とと関係があるようである。

石英のような粉体では, 図-4に示すようにらポテン

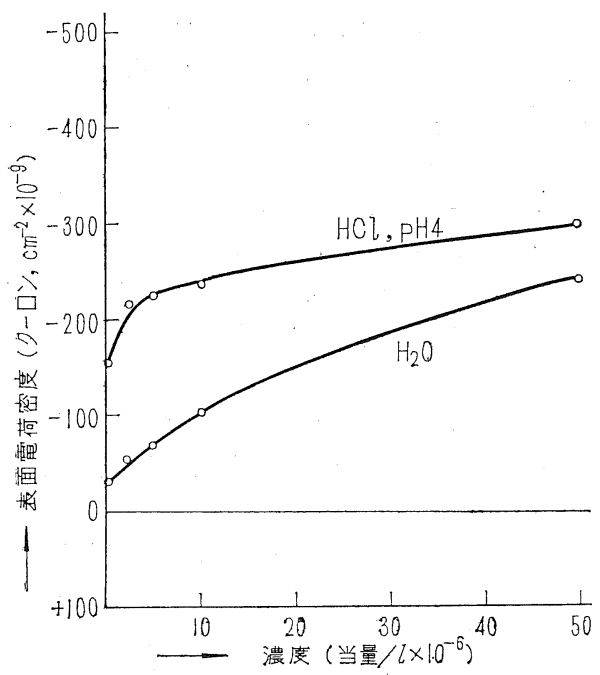

図-4 石英の表面電荷密度に及ぼす陰イオン 捕収剂 SCS の効果
シャルより求められた表面電荷密度は, 界面活性剂濃度 の増加によって陰イオン界面活性剤セチル硫酸ナトリウ 么 SCS では, その負の表面電荷密度を増して, 界面活 性剤の吸着が物理吸着に基づくことを示し9，また陽イ オン界面活性剤ラウリルトリメチルアンモニウムでは, 負の表面電荷密度が正にその符号を逆転, 増加して, 物 理吸着のほかに陽イオン交換が起とるととを示してい $3^{9)}$ 。

\section{$1.2 \mathrm{pH}$}

$\mathrm{pH}$ したがって水素イオン濃度および水酸イオン濃度 は, 固体面のポテンシャル決定イオンとされている ${ }^{12)}$ のでpH は界面活性剤水溶液中における固体のらポテン シャルにも相当の影響を及ぼす。

陽イオン界面活性剤 DPB 水溶液中における羊毛で は, 図-51) そ示すように, $\mathrm{pH}$ のアルカリ性側より酸性 側に移るに従って，らポテンシャルはその符号を負よ? 正に逆転して 増加し， $\Delta \sigma$ はアルカリ性側の方か酸性側 よりも大きい。 $\Delta \sigma$ がてのような傾向となるのは, 界面活 性剤が陽イオン性であり, 羊毛の有するカルボキシル基 が吸着の対象となるためであろう。

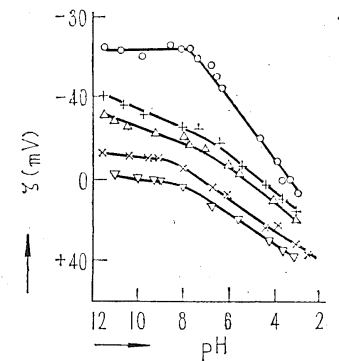

(a)

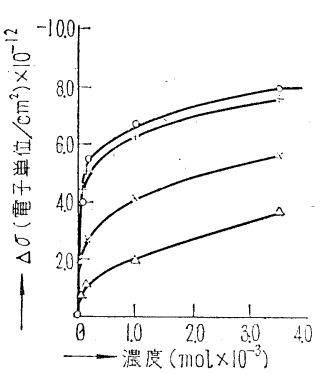

(b) (a) $\zeta$-pH の関係; DPB 濃度 $\alpha^{\prime}=0, \beta=6 \times 10^{-5} \mathrm{~mol}, \gamma=2 \times 10^{-4} \mathrm{~mol}$ $\delta=10^{-3} \mathrm{~mol} \varepsilon=3.6 \times 10^{-3} \mathrm{~mol}$

(b) $\Delta \sigma$-濃度の関係; 一- - - $\mathrm{pH} \mathrm{9,-+-+-} \mathrm{pH} 7,-\times-\times-$ $\mathrm{pH} 5,-\Delta-\Delta-\mathrm{pH} 3$

\section{図-5}

また図-2(b),(d) のように,ナイロンについて，陰イ オン界面活性剤 SDS ではらは $\mathrm{pH} 11$ の方が $\mathrm{pH} 3$ より 負側により， $\Delta \sigma$ は $\mathrm{pH} 3$ の方が $\mathrm{pH} 11$ より大となり，陽 イオン界面活性㓮 DPB では くは pH 11 の方が $\mathrm{pH} 3$ よ り負側により， $\Delta \sigma$ は $\mathrm{pH} 11$ の方が $\mathrm{pH} 3$ より大となって いる。これらのととは陽イオン界面活性剤では酸性側の 方が吸着が大であり陽イオン界面活性剤ではアルカリ性 側の方が吸着が大であるととな示し，当然のととながら これらの結合としては主として静電結合が考えられる。

粉体の石英表面に対する陽イオン界面活性剤酢酸ドデ シルアンモニウム DAA一濃度 $4 \times 10^{-5} \mathrm{~mol}$ - (CMC 1.3 $\left.\times 10^{-2} \mathrm{~mol}\right)$ の吸着に関しては，図-6のようにらポテン シャルに対する $\mathrm{pH}$ の影響が調べられ 8 , $\mathrm{pH}$ 約 9 にお いてーらポテンシャルの極大が生ずるのは，石英界面で 界面活性倣吸着分子が会合体一界面々セルあるいは半ミ 
セル (hemi-micelle) を形成するためであると考えられ ている。

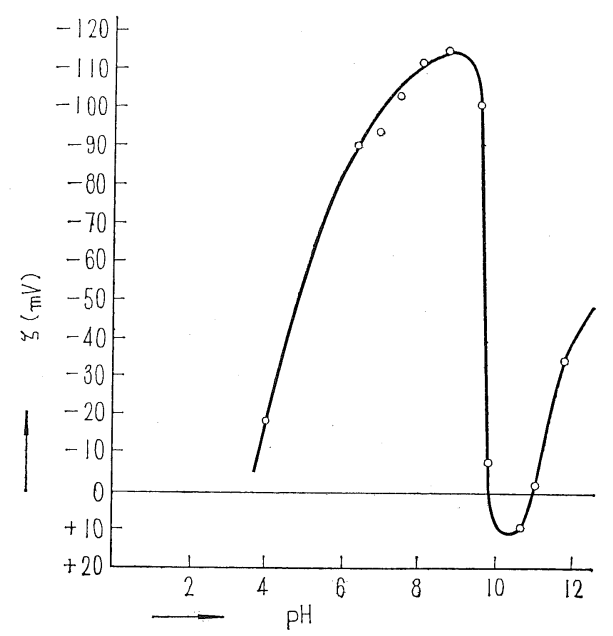

酶酸ドデンルアンモニウム濃度: $4 \times 10^{-5} \mathrm{~mol}$

図-6 石英のらポテンシャルに及ぼす $\mathrm{pH}$ の影響

そしてさらに pHが高いととろでらの符号が正より負 に転ずる原因としては，遊離アミンの形成および $\mathrm{Na}^{+}$ （pH 調節のためのカセイソーダに基因）と界面活性剤陽 イオンとの間の競争吸着に基づくとされている。

\section{3 アルキル基の長さ}

図-7 はアルキル硫酸ナトリウム同族体（オクチル $\mathrm{C}_{8}$ $\mathrm{SOS}$, ドデシル $\mathrm{C}_{12} \mathrm{SDS}$, テトラデシル $\mathrm{C}_{14} \mathrm{STS}$ および セチル $\left.\mathrm{C}_{16} \mathrm{SCS}\right)$ 中におけるナイロン 6 の ポテンシャ ルを示した ${ }^{3 b)}$ もであるが，それぞれのら-界面活性剤

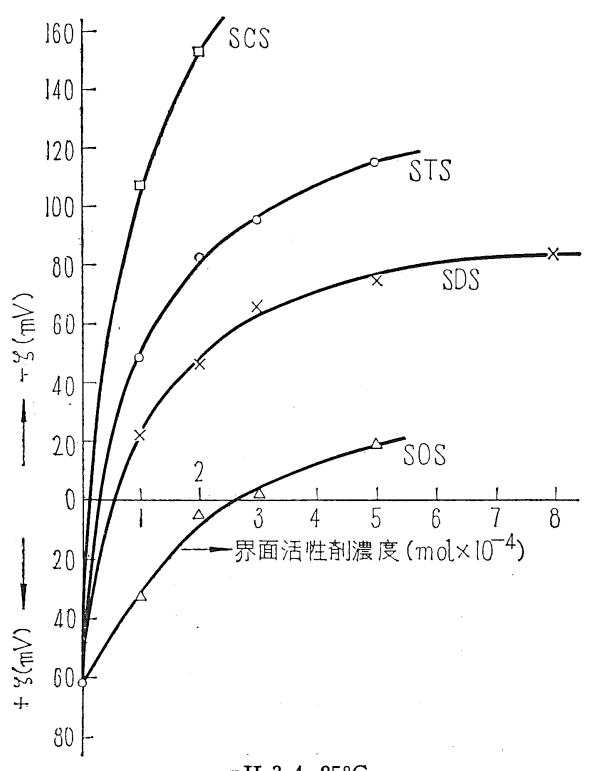

$\mathrm{pH} 3.4,25^{\circ} \mathrm{C}$

図-7 アルキル硫酸ナトリウム同族体水溶液中のナイロン 6 のらポテンシャルに及ぼす炭化水素鎖長の影響
濃度曲線は，炭化水素鎖の長いほど—SCS >STS >SDS $>\mathrm{SOS}$ の順に一低濃度側にずれることを示す。

また種々の酢酸アルキルアンモニウム（オクチル OA $\mathrm{A}$, デシル DAA, ドデシル DDAA, テトラデシル TAA およびへキサデシル HAA）水溶液中における石英の ポテンシャルを調べた結果 ${ }^{8)}$ では, 酢酸アルキルアンモ ニウムのある濃度で，らは負より正にその符号を逆転す るが，乙の逆転はアルキル基の長さの長いほど低濃度で 起こる。

これらの事実はカーボンブラックニよるアルキル硫酸 ナトリウム同族体 $\left(\mathrm{C}_{12}, \mathrm{C}_{14}, \mathrm{C}_{16}, \mathrm{C}_{18}\right)$ の吸着について ${ }^{13)}$, $\mathrm{Al}_{2} \mathrm{O}_{3}$ による塩化アルキルアンモニウム $\left(\mathrm{C}_{12}, \mathrm{C}_{14}, \mathrm{C}_{16}\right)$ の吸着について ${ }^{14)}$ ，いずれもアルキル基の長いほど吸着 等温線は低濃度側にずれると報告されているのとよく対 応し, 固体表面への界面活性剤の炭化水素鎖によるファ ンデルワールスカによる吸着を示唆する。

\section{CMC 付近の界面活性剂濃度の場合}

界面活性剤がその水溶液から繊維などの固体に吸着す るとき, その等温吸着曲線は界面活性剤の $\mathrm{CMC}$ の濃度 で折点を生じ, CMC より少し高い濃度で吸着量の極大 が現われ，さらに高濃度では吸着量は減少する。乙の現

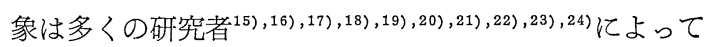
報告され，また吸着量の極大か覞われる原因については いろいろの考方方がある。

この現象に関連して,繊維について $\zeta$-界面活性剤濃度 の関係を $\mathrm{CMC}$ 付近について調べた例はつぎのように 三,三みられる。

セチル 硫酸 ナトリウム $\mathrm{SCS}\left(\mathrm{pH} 11,55^{\circ} \mathrm{C}\right)$ 水溶液中 で, モメンと羊毛のらポテンシャルは界面活性剤の CMC $\left(5 \times 10^{-4} \mathrm{~mol}\right)$ 以上では一定となるととがみられ

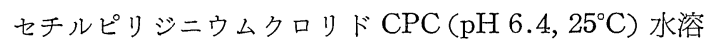
液中で,モメンのらポテンシャルは $\mathrm{CMC}\left(6.8 \times 10^{-4} \mathrm{~mol}\right)$ 付近で $+\zeta$ の極大を示し, それ以上の濃度では減少する ことが認められている1。

さらにアルキル硫酸ナトリウム同族体 $\left(\mathrm{C}_{10}, \mathrm{C}_{12}, \mathrm{C}_{14}\right)$ の水溶液中におけるモメン, 羊毛, 絹, ビスコース人綟, ナイロンなどのらポテンシャルは, 界面活性剤の CMC 付近で繊維の 種類によってーらの山を生じたり生じなか ったりするととが知られている゙2。

上に述べたように, 繊維類の場合には, 界面活性剤の $\mathrm{CMC}$ とポテンシャルとの間になんらかの関係は認め られるが明確ではない。

著者は陽イオン界面活性剤のアルキル硫酸ナトリウム SDSおよび STS の水溶液中におけるナイロン 6 の テンシャルを調べ25), 界面活性剤の CMC (SDS, $7 \times$ $10^{-3} \mathrm{~mol}, \mathrm{pH} 6.2,25^{\circ} \mathrm{C}$; STS, $\left.2 \times 10^{-3} \mathrm{~mol}, \mathrm{pH} 6.6,35^{\circ} \mathrm{C}\right)$ の濃度で，一らが極大になることを知った。また表面電 
荷密度の差 $\Delta \sigma$ より 求めた界面活性剤の 表面吸着量-界 面活性剤濃度曲線は CMC で折点を生じ, CMC 以上の 濃度ではさらに表面吸着量が増加するととを認めた。し たがっててれらの事実は，上にも述べた界面活性剤の繊 維に対する等温吸着曲線が CMC で折点を生じ, CMC 以上でさらに吸着量か増加するという事実とよく対応す る。らポテンシャルが CMC で極大を生ずる原因として は，電気二重層の厚さの圧縮あるいは吸着した之セル表 面における濃厚なイオン雾囲気によるミセルの電荷の遮 蔽效果が考えられる。しかし等温吸着曲線が CMC より 高濃度で吸着量の極大を生ずる原因についてはなお検討 が必要であうう。

\section{3 洗浄作用亡らポテンシャル}

界面活性剂の洗浄作用は, 界面活性剂自身の界面活 性，ヌレ，粒子分散および油脂分乳化など種々の作用が 関与する複雑な現象と考えられる。そして一応基質（被 服瀻維類など), 污垢, 洗凬溶液の三者か関与している が，污垢類を基質より除去あるいは污坧類が基質化再沈 着する過程は界面電気化学的にみて最もらポテンシャル と関係か深い。これらの過程では污垢と洗剤溶液間およ び基質と洗剤溶液間のらポテンシャルがかなり問題とな り，一般にはこれらの間のらポテンシャルが高ければ高 いほど，洗浄効果は大きいとされている ${ }^{26)}$ 。そして污垢 および基質のらポテンシャルの符号および大きさを決定 するものは，洗剤溶液汃優先的にてれらに吸着される イオンである。したがって陰イオン界面活性剤または陽 イオン界面活性剤では, その対イオンよりも, 界面活性 剤陰イオンまたは界面活性剤陽イオンが優先的に吸着さ れるので，1.1亿みてきたように繊維などに対して，通 常陰イオン界面活性剤では負のらポテンシャルを増し，

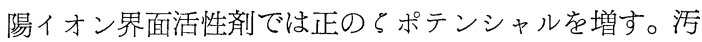
垢は水溶性, 油性および固形の 3 種類に分けられるが, 洗浄作用を考光る場合後二者か対象となり，てれらのも のはその多くが負の電荷を有しているが，陰イオンおよ び陽イオン界面活性剤水溶液中では, 繊維のときと同様 にそのらポテンシャルを変化する。非イオン界面活性剤 の洗浄性とらポテンシャルの関係については十分な研究 が行なわれていない。

上に述べた事柄について，つぎに界面活性剤別に二， 三の例をあげて説明する。なお繊維類のらポテンシャル は先に述べたので省略し，污垢物質の界面活性剂水溶液 中でのらポテンシャルについておもに述べながら説明を 加光るが，污坧物質として対象となるのは油性あるいは 固形の粒子であるので, 実験方法として電気泳動的な方 法が用いられ，しばしばらポテンシャルの代わりに易動 度で表わされているてとがある。

\section{1 陰イオン界面活性剤の場合}

\section{表-2}

\begin{tabular}{c|c}
\hline $\begin{array}{c}\text { ラウリン酸 } \\
\text { ナトリヴ } \\
(\mathrm{mol}) \times 10^{3}\end{array}$ & $\begin{array}{c}\text { ラウリン酸陰 } \\
\text { イオンの電何 }\end{array}$ \\
\hline $0 \sim 6^{*}$ & 1 \\
$6 \sim 21$ & 2 \\
$21 \sim 28^{* *}$ & 4 \\
$28 \sim 37$ & 6 \\
\hline
\end{tabular}

注）*1-1 電解質 $* * \mathrm{CMC}$
ラウリン酸ナトリウムの ようなセッケンでは,つぎ に示すようにその濃度増加 とともにその価数を増すと とが知られている ${ }^{27)}$

したがっててのような界 面活性剂陰イオンが污垢ま たは繊維に吸着されるので あるから，そのーらポテンシャルが増加するのは当然で ある。

つぎに污㕵のモデル物質としての油滴, カーボンおよ び酸化第二鉄粒子のらポテンシャルに及ぼすセッケンの 影響を表(示す ${ }^{28)}$ 。

\begin{tabular}{|c|c|c|c|}
\hline \multicolumn{4}{|c|}{ 表-3 } \\
\hline \multirow[b]{2}{*}{ 溶 } & \multicolumn{3}{|c|}{ らポテンシャル (V) } \\
\hline & $\begin{array}{l}\text { パラフィン } \\
\text { 油 滴 }\end{array}$ & カーボン & 酸 \\
\hline 水 & 0.086 & -0.052 & -0.028 \\
\hline パルミチン酸ナトリウム & - & -0.069 & - \\
\hline オレイン酸ナトリウム & -0.151 & -0.083 & - \\
\hline 希薄セッケン溶液 & - & - & -0.078 \\
\hline
\end{tabular}

ての表からセッケンが存在するときには，固形あるい は油性の粒子はーらポテンシャルを增し，てれらの系の サスペンジョンあるいはエマルジョンは安定となるとと がわかる。

図-8 はSDS 溶液中におけるカーボン, 酸化鉄および リグナイト粒子の陽極への易動度を示した ${ }^{29)}$ もである が，カーボンとリグナイトの界面活性剤濃度による易動 度の変化曲線は似ており，酸化鉄のそれは前二者とはか なり異なる。しかしいずれも界面活性剤濃度の増加とと も晹動度を増し, 特に CMC で曲線に折点が生ずるの は, 2 の繊維の $\zeta$ ポテンシャルと $\mathrm{CMC}$ の関係と対比し て興味がある。

このほかアルキルベンゼンスルホン酸ナトリウム水溶

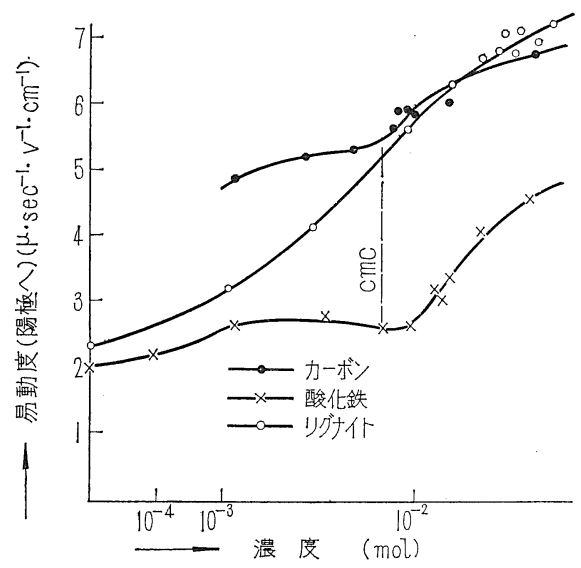

図-8 院イオン界面活性剤 SDS 溶液中の易動度 
液中のカーボン粒子の易動度 ${ }^{29}$ あるいはビルダーとして の無機塩類の加わった系の易動度 ${ }^{30)}$ を調べた例などもあ る。また脂肪酸セッケン水溶液中でカーボンの陽極への 易動度あるいは一らポテンシャルが，セッケンの炭化水 素鎖長によって増加する ${ }^{28)}$ とも報告されている。

いずれにしても，上に述べたてとおよび 1 1で述べた ととより，污坧物質も基質となる瀻維類もともに，陰イ オン界面活性剤中では，そのーらポテンシャルを增すて とが考光られ，したがってお互いの間の電気的反發力を 増して，洗浄効果があがると思われる。

\section{2 陽イオン界面活性剤の場合}

陽イオン界面活性剤ドデシルピリジニウムクロリド DPC 溶液中のカーボン, 酸化鉄などの粒子の陰極への 易動度を示したのが図-930) であるが，てれらの粒子は 負より正に荷電するととがわかる。との結果は，陽イオ ン界面活性剤がある濃度以上では，污垢粒子が強く正に 荷電し，同じく正に荷電した繊維物質などの基質との間 亿電気的反势力を生じ，洗浄効果が現われる可能性を示 唆する。また油性污垢が陽イオンセッケンの濃度の高い 場合に除去される26) といわれているのも同じ理由による ものであろう。

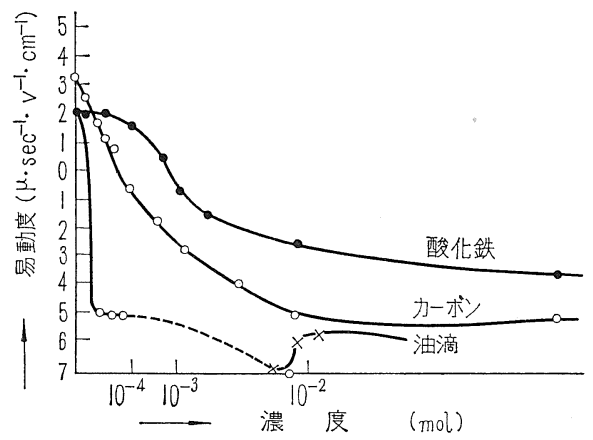

図-9 陽イオン界面活性率 DPC 溶液中の粒子の易動度

\begin{tabular}{|c|c|c|c|}
\hline \multicolumn{4}{|c|}{ 表-4 } \\
\hline \multirow{3}{*}{$\begin{array}{c}\text { Hyamine } \\
1622^{*} \\
\text { 濃度 }(\%)\end{array}$} & \multicolumn{3}{|c|}{ 易動度 $\mu / \mathrm{sec} / \mathrm{volt} / \mathrm{cm}$} \\
\hline & \multirow{2}{*}{$\begin{array}{c}\text { セルロース } \\
0.2 \%\end{array}$} & \multicolumn{2}{|c|}{ カーボン $0.2 \%$} \\
\hline & & Excelsior & Molacco \\
\hline 0 & -1.3 & -1.8 & +2.1 \\
\hline 0.001 & +0.30 & - & $\longrightarrow$ \\
\hline 0.01 & +1.8 & +3.8 & +6.2 \\
\hline 0.10 & +2.8 & +6.8 & +8.5 \\
\hline 0.25 & $\longrightarrow$ & +7.3 & - \\
\hline 0.5 & - & - & +9.5 \\
\hline 0.75 & - & +7.0 & - \\
\hline 1.0 & +3.0 & - & - \\
\hline 1.5 & $\longrightarrow$ & +7.6 & +8.8 \\
\hline 3.0 & +3.2 & +7.9 & +9.2 \\
\hline
\end{tabular}

注）* ジイソブチルフェノキシェチルジメチルベンジル アンモニウムクロリド一水塩
しかし 表-4411 に示したように，モメンとカーボン類 の電荷が，陽イオン界面活性剤の濃度増加によって，全 然接近しないのは, 電気的反势力よりも電気的吸引力が ある程度作用するととを示唆し，少なくとも十分な洗浄 効果のないととを示す。

てのようなととから考学ると，洗剤溶液中で陽イオン 界面活性剂の場合には，一度基質より除去された污坧物 質が，再び基質上に再沈着するとともありうるわけであ る。

\section{3 非イオン界面活性剤の場合}

ドデシルアルコールとエチレンオキシド $(15 \mathrm{~mol})$ よ りなる非イオン界面活性剤水溶液中における, カーボン および酸化鉄の易動度が調べられている ${ }^{29)}$ が，界面活性 剤濃度による変化はほとんどない。

一方繊維物質などでは，1・1で述べたように界面活性 剤の濃度増加とともに，十方増加するととが認められ ている。

しかし，一般に非イオン界面活性剂の洗浄作用を説明 するに十分な研究が行なわれていない現状である。

\section{4 浮遊選鉱亡 $\zeta$ ポテンシャル}

浮遊選鉱とは，水中に懸濁した数種の釷石の細粉粒子 の中から，有用鉱物を気木ウを用いて浮かせ，選別する 方法である。したがって気ホウを作りやすい薬剤として の起ホウ剤と，有用鉱物にだけ選択的に吸着してその表 面を踈水性化する試薬としての捕収剤が特に重要であ る。浮選の基礎的研究としてはこのうち鉱物表面への捕 収剂の财着，いいかえれば鉱物を気ホウに付着しやすく するための鉱物表面の疎水性化の問題が取りあげられて きた。

らポテンシャルが関与する研究も，乙の鉱物表面への 捕収剤の吸着に関してのものが多い。そして石英の陽 オンあるいは陰イオン捕収剂による研究がらポテンシャ ル測定によって行なわれている。图一拈よび図一ももそ の例である。

特に注目すべきてとは 1.2の図-6 で述べたように， 酢酸ドデシルアンモニウム分子が石英表面で一種の会合 体としての hemi-micelle を形成するといわれていると とで，とのととに関してはドデシルアンモニウムクロリ ドについてもいわれている8

すなわちドデシルアンモニウムクロリドの濃度の対数 とらポテンシャルの関係を目盛ってみると, 濃度が低い 間は食塩などと同様の ら-濃度曲線を示し，ドデシルアン モニウム陽イオンは一価の $\mathrm{Na}^{+}$と同様に 単独イオンと して石英に吸着していることを示すが，ある濃度に達す るとそのらポテンシャルは急触より正への符号の逆転 を生ずる。このととはその濃度で石英表面に吸着したド デシルアンモニウム陽イオンの状態に変化を生じた証抛 
と考光られ，らポテンシャルの符号の逆転が $\mathrm{Ba}^{++} や$ $\mathrm{Al}^{+++}$のような多価の陽イオンの場合のようであるてと から，上の事実はドデシルアンモニウム陽イオンか沰英 表面において，あたかも水溶液中でミセルを形成するの と同様な方法で集合しているととを示唆するものとして いる。乙の石英表面で生ずる界面活性剤陽イオンの集合 体を hemi-micelle としているのである。

また酶酸ドデシルアンモニウムの濃度一定の条件で, 石英表面の接触角，らポテンシャルおよび浮選実収率に 及ぼす $\mathrm{pH}$ の影響が調べられた ${ }^{10)}$ が，図-10に示したよ うにてれらの間に密接な関係のあるてとが見出された。

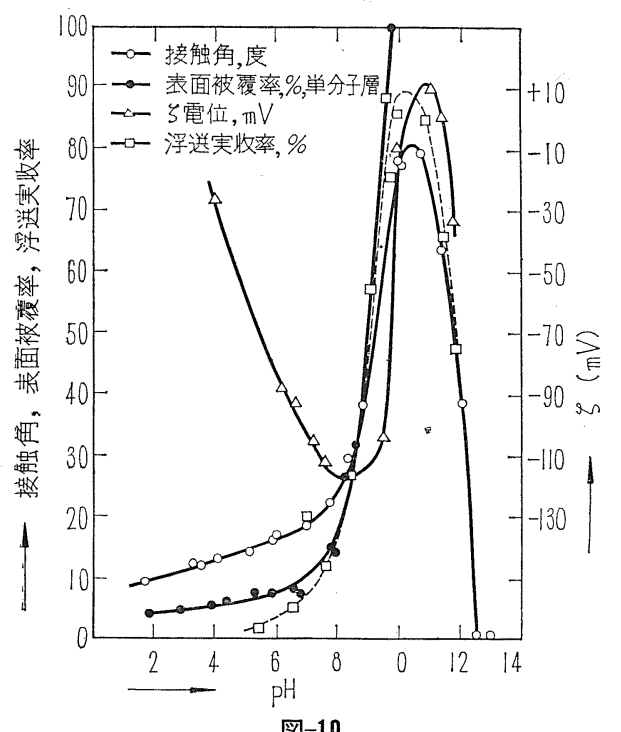

$\mathrm{pH} 8$ 付近のこれらの值の急変は，ドデシルアンモニ ウム陽イオンによる hemi-micelle の形成に対応してお り, $\mathrm{pH}$ が高くなるに従って石英表面の負電荷は当然大 となり，その結果ての大きな負電荷の対イオンとしての ドデシルアンモニウム陽イオンの濃度が高くなり, hemi-micelle を形成するようになるという。

このほか磁鉄鉱について，捕収剂としてのオレイン酸 ナトリウムの吸着量とその浮遊性あるいは凝集, 分散と の関係を，らポテンシャルと沈降容積によって調べた 例 ${ }^{32)}$ ，蛍石および石英とドデシルベンゼンスルホン酸ナ トリウムの系, 重石および石英とオクタデシルジメチル ベンジルアンモニウムクロリドの系について，てれらの 捕収剤イオンの吸着とらポテンシャルの関係を調べた 例 $^{33)}$ ，七チル硫酸ナトリウム，オレイン酸ナトリウム， ラウリルトリメチルアンモニウムブロミドおよび酶酸ド デシルアミンと重石の系について同様のととを調べた 例年)などがある。

\section{5 染色亡り ポテンシャル}

染色は染浴と繊維の界面か関与するので, らポテンシ
ヤルが当然問題となる。てれらについては別の機会にも ふれた ${ }^{35}$ が，本稿では界面活性羭との関係において染色 におけるらポテンシャルを取り上げる。

陰イオン界面活性剤は通常羊毛あるいはナイロンなど の酸性染料による染色のときに緩染㓮として用いられる が,アルキル硫酸ナトリウムは瀻維のーらポテンシャル を増加させ, 染料陰イオンとの競合によって染着量を減 少させるとと，また界面活性剤の炭化水素鎖の長いほど 上の傾向が大きいととが認められだ

ポリアクリロニトリル繊維を陽イオン染料と陰イオン 界面活性剤觉一緒に入れた染浴で染色する際の繊維表面 の染料财着をらポテンシャルによって研究し, 染着速度 との関係を調べている ${ }^{36)}$ 。

また塩化ビニル系瀻維を反対荷電を有する染料および 界面活性剤で染色する場合の染色機構がらポテンシャル で研究されている5 。

\section{6 そ $の$ 他}

また製紙工業におけるサイジングの工程は，ロジンセ ッケンなどが関与し，らポテンシャルがかなり重要な因 子となっている。

このほか乳化，分散などに関連して 種々の問題があ り，らポテンシャルの測定はその解明に有用であるが， それらについては別の機会にゆずる。 (昭和 37 年 9 月 17 日受理)

\section{文献}

1) J.S. Stanley, J. Phys. Chem., 58, 533 (1954)

2) M.v. Stackelberg, W. Kling, W. Benzel, F. Wilke, Kolloid Z., 135, 67 (1954)

3）須沢, (a) 工化, 82, 473 (1959); 63, 151 (1960) (b) 日化コロイド化学討論会講演 (1961); 工化投稿中

4) 須沢，日化コロイド化学討論会講演要旨 (1962)

5）山木。“塩化ビニル䒺合成繊維を染色する際の染料と界面 活性剂の相互作用”, p. 71 (1962)

6）須沢，日化第 14 年会講演 (1961)

7) A.M. Gaudin, D.W. Fuerstenau, Min. Eng., 7, 958 (1955)

8) D.W. Fuerstenau, .J. Phys. Chem., 60, 981 (1956)

9) D.J. O'Conner, A.S. Buchanan, Trans.Faraday Soc., 52, 397 (1956)

10) D.W. Fuerstenau, Min. Eng., 9, 1365 (1957)

11) B. Wurzschmitt, Z. analyt. Chem., 130, 127 (1949); W. Scholtan, Makromol. Chem., 11, 131 (1953)

12) H.R. Kruyt, "Colloid Science," Vol 1, 226 (1952)

13) G.R.F. Rose, A.S. Weatherburn, C.H. Bayley, Textile Research J., 21, 427 (1951)

14) B. Tamamushi, K. Tamaki, Proc. Int. Congr. Surface Activity, 2nd, 3, 449 (1957)

15) R.G. Aickin, J. Soc. Dyers. Colourrists, 60, 60 (1944)

16) W.D. Harkins et al., J. Colloid Sci., 4, 485 (1949)

17) A.L. Meaden, B.A. Fries, Ind. Eng. Chem., 44, 1636 (1952)

18) A. Fava, H. Eyring, J. Phys. Chem., 60, 890 (1956)

19) R.D. Vold, Phansalkar, Rec. trav. Chim., 74, 41 (1955)

20) R.D. Vold, Sivaramakrishnan, J. Phys. Chem., 62, 984 (1958)

21) H.C. Evans, J. Colloid Sci., 13, 537 (1958) 
22）佐々木, 日化コロイド化学討論会特別講演要旨集, p. 57 (1959)

23) F.H. Sexsmith, H.J. White, J. Colloid Sci., 14, 598,630 (1959)

24）立花, 日化コロイド化学討論会講演要旨集, p. 57 (1959)

25）須沢，日化第 15 年会講演 (1962)

26) E.K. Goette, J. Colloid Sci., 4, 459 (1949)

27) P.E. Kwall, L.G. Lindblad, Kolloid Z,. 94, 42 (1941)

28) W.M. Urban, L.B. Jensen, J. Phys. Chem., 40, 821 (1936)

29) W. Kling, H. Lange, Kolloid-Z., 127, 19 (1952)
30) J.C. Harris, Textile Research J., 28, 921 (1958)

31) T.M. Doscher, J. Colloid Sci., 5, '100 (1950)

32）臼井，下飯坂，浮選， 11，5 (1959)

33) 向井, 加納, 松原, 藤井, 日鉱, 75, 167 (1959) S. Mukai,G. Kano, T. Matsubara, Mem. Fac. Eng. Kyoto Univ., 21, 40 (1959)

34) D.J. O'Connor, Proc. Int. Congr. Surface Activity, 2nd, London, 3, 319 (1957)

35）須沢，コロイドと界面活性剂，1，345 (1960)

36) W. Beckmann, Proc. Int. Congr. Surface Activity 3rd, (1960)

\section{会䛱“油化 学”バックナンバー在庫おしらせ}

既刊 “油化学”は下記のとおり在庫しております。ご入用の方は協会あて，代金と送料を添えてお申し越し下さ い。下欄の数字は各 1 部の金額で送料は各 1 部 30 円（ただし，Vol．6．No， 7 のみ 50 円）でございます。

\begin{tabular}{|c|c|c|c|c|c|c|c|c|c|c|c|c|}
\hline 巻 (年) 号 & 1 & 2 & 3 & 4 & 5 & 6 & 7 & 8 & 9 & 10 & 11 & 12 \\
\hline 1 (1952) & $150^{\mathrm{円}}$ & $150 \mathrm{円}$ & 150円 & 150 & 一円 & —円 & _-円 & —円 & —円 & 一円 & 一円 & 一円 \\
\hline 2 (1953) & 150 & 150 & 150 & 150 & 150 & 150 & - & - & - & - & - & - \\
\hline 3 (1954) & - & - & - & 150 & 150 & 150 & - & - & - & - & - & - \\
\hline $4(1455)$ & - & - & - & 150 & 150 & 150 & - & - & - & - & - & - \\
\hline $5(1956)$ & 150 & 150 & 150 & 150 & 150 & 150 & - & - & - & - & - & - \\
\hline 6 (1957) & 150 & 150 & 150 & 150 & 150 & 150 & $250 *$ & - & - & - & - & - \\
\hline 7 (1958) & - & 150 & 150 & 150 & $200 *$ & 150 & 150 & $200 *$ & - & - & - & - \\
\hline 8 (1959) & - & 150 & 150 & 150 & 150 & $200 *$ & 150 & $250 *$ & 200 & 250 & 200 & $250^{*}$ \\
\hline $9(1960)$ & $200 *$ & 200 & 200 & 200 & $250 *$ & 200 & 250 & 200 & 200 & 250 & 200 & 200 \\
\hline 10 (1961) & 250 & $250^{*}$ & 250 & 250 & 200 & $200^{*}$ & 250 & 250 & 200 & 250 & - & 250 \\
\hline $12(1962)$ & 200 & 200 & 200 & 200 & 200 & 250 & 200 & 200 & 200 & 200 & $250^{*}$ & \\
\hline
\end{tabular}

*特 集 号

$\begin{array}{ll}\text { Vol. 6, No. } 7 & \text { 「界面活性剤の進歩」 } \\ \text { Vol. 7, No. } 5 & \text { 「酸化と酸化防止」 } \\ \text { Vol. 7, No. } 8 & \text { 「レオロジー」 } \\ \text { Vol. 8, No. } 6 & \text { 「水添と還元」 } \\ \text { Vol. 8, No. } 8 & \text { 「石油化学と油脂化学との関連領域」 } \\ \text { Vol. 8, No. } 12 & \text { 「クロマトグラフィーI」 } \\ \text { Vol. 9, No. } 1 & \text { 「クロマトグラフィーII」 } \\ \text { Vol. 9, No. } 5 & \text { 「日本における界面活㤬研究の展望」 } \\ \text { Vol.10, No. } 2 & \text { 「油と金属」 } \\ \text { Vol.10, No. } 6 & \text { 「脂質と生化学」 } \\ \text { Vol.11. No. } 11 & \text { 「脂肪酸の機器分析」 }\end{array}$

